DEVELOPMENT OF A PRACTICAL PHOTOCHEMICAL ENERGY STORA GE SYSTEM

Quarterly Report This report was prepared as an account of work
sponsored by the United States Government. Neither the
United States nor the United States Department of
Energy, nor any of their employees, nor any of their
contractors, subcontractors, or their employees, makes
any warranty, express or implied, or assumes any legal
liability or responsibility for the accuracy, completeness
or usefulness of any information, apparatus, product or
process disclosed, or represents that its use would not
intringe privately owned rights.

Richard R. Hautala and Charles R. Kutal

Department of Chemistry

University of Georgia

Athens, Geogia 30602

December 15, 1978

PREPARED FOR THE

U.S. Department of Energy

UNDER CONTRACT EY-76-S-09-0893 


\section{DISCLAIMER}

This report was prepared as an account of work sponsored by an agency of the United States Government. Neither the United States Government nor any agency Thereof, nor any of their employees, makes any warranty, express or implied, or assumes any legal liability or responsibility for the accuracy, completeness, or usefulness of any information, apparatus, product, or process disclosed, or represents that its use would not infringe privately owned rights. Reference herein to any specific commercial product, process, or service by trade name, trademark, manufacturer, or otherwise does not necessarily constitute or imply its endorsement, recommendation, or favoring by the United States Government or any agency thereof. The views and opinions of authors expressed herein do not necessarily state or reflect those of the United States Government or any agency thereof. 


\section{DISCLAIMER}

Portions of this document may be illegible in electronic image products. Images are produced from the best available original document. 
"This report was prepared as an account of work sponsored by the United States Government. Neither the United States nor the United States Department of Energy nor any of their empolyees, nor any of their contractors, subrontractors, or their empolyees, makes any warranty, express or implied, or assumes any legal liability or responsibility for the accuracy, completeness or usefulness of any information, apparatus, product or process disclosed, or represents that its use would not infringe privately-owned rights." 


\section{RESEARCH SUMMARY}

During the past three-month period of this project, we submitted for publication our results on the use of a class of copper(I)-phosphine compounds as inorganic photosensitizers for the norbornadiene to quadricyclene conversion. A-copy the-monuseriptis-appendedto thig-eport.

We have also continued our investigation of the sensitization behavior of $\operatorname{Ir}(\text { bipy })_{2}-$ (bipy') $\mathrm{OH}_{2}^{+3}$ which has been immobilized onto carboxylated silica gel. One possible drawback in using such a solid support arises from the loss of incident light due to scattering. We have examined this effect for our carboxylated silica gel (containing no sensitizer) in a variety of solvents. As summarized in Table I, norbornadiene turns out to be an almost ideal liquid phase for minimizing losses due to scattering (i.e. it gives rise to a low apparent absorbance).

\section{TABLE I}

\begin{tabular}{lc} 
Liquid Phase & Absorbance* \\
\cline { 2 - 2 } norbornadiene & 0.25 \\
methanol & 1.98 \\
ethanol & 1.92 \\
acetonitrile & 2.0 \\
hexane & 1.74 \\
benzene & 0.93 \\
cyclohexane & 1.24 \\
tetrahydrofuran & 1.53 \\
Measured for carboxylated silica gel plus liquid \\
in a 1 mm cell vs. pure liquid as a reference.
\end{tabular}

Quantum yield studies reveal that the initial efficiency of quadricyclene production for the immobilized Ir sensitizer is quite high, but diminishes upon prolonged irradiation. Moreover, some disappearance of the starting material also occurs. Our current feeling is that both problems arise from the presence of trapped oxygen in the silica gel. Future work will be directed toward minimizing these difficulties with the goal of improving the long-term stability of the immobilized sensitizer.

Furthermore, a study involving the quantitative comparison of immobilized organic sensitizers has reached a reasonable level of completion. mentoriptis 


\title{
DEVELOPMENT OF A PRACTICAL PHOTOCHEMICAL ENERGY STORAGE SYSTEM \\ Quarterly Report
}

\author{
Richard R. Hautala and Charles R. Kutal \\ Department of Chemistry \\ University of Georgia \\ Athens, Geogia 30602
}

December 15, 1978

PREPARED FOR THE

U.S. Department of Energy UNDER CONTRACT EY-76-S-09-0893 
"This report was prepared as an account of work sponsored by the United States Government. Neither the United States nor the United States Department of Energy nor any of their empolyees, nor any of their contractors, subrontractors, or their empolyees, makes any warranty, express or implied, or assumes any legal liability or responsibility for the accuracy, completeness or usefulness of any information, apparatus, product or process disclosed, or represents that its use would not infringe privately-owned rights." 


\section{RESEARCH SUMMARY}

During the past three-month period of this project, we submitted for publication our results on the use of a class of copper $(1)$-phosphine compounds as inorganic photosensitizers for the norbornadiene to quadricyclene conversion. A copy do to -

We have also continued our investigation of the sensitization behavior of $\operatorname{Ir}(\text { bipy })_{2}$ : (bipy') $\mathrm{OH}_{2}^{+3}$ which has been immobilized onto carboxylated silica gel. One possible drawback in using such a solid support arises from the loss of incident light due to scattering. We have examined this effect for our carboxylated silica gel (containing no sensitizer) in a variety of solvents. As summarized in Table I, norbornadiene turns out to be an almost ideal liquid phase for minimizing losses due to scattering (i.e. it gives rise to a low apparent absorbance).

\section{TABLE I}

\begin{tabular}{lc} 
Liquid Phase & Absorbance* \\
\cline { 2 - 2 } norbornadiene & 0.25 \\
methanol & 1.98 \\
ethanol & 1.92 \\
acetonitrile & $>2.0$ \\
hexane & 1.74 \\
benzene & 0.93 \\
cyclohexane & 1.24 \\
tetrahydrofuran & 1.53 \\
Measured for carboxylated silica gel plus liquid \\
in a $1 \mathrm{~mm}$ cell vs. pure liquid as a reference.
\end{tabular}

Quantum yield studies reveal that the initial efficiency of quadricyclene production for the immobilized Ir sensitizer is quite high, but diminishes upon prolonged irradiation. Moreover, some disappearance of the starting material also occurs. Our current feeling is that both problems arise from the presence of trapped oxygen in the silica gel. Future work will be directed toward minimizing these difficulties with the goal of improving the long-term stability of the immobilized sensitizer.

Furthermore, a study involving the quantitative comparison of immobilized organic sensitizers has reached a reasonable level of completion. $A$ eepy-of a recenty prepared

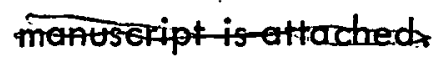

